\title{
Impactos da Substituição Tributária do ICMS na Lucratividade e nos Custos Empresariais
}

\author{
Impacts of the ICMS Tax Substitution Profitability and Business Costs
}

\author{
Roberto Biava Júnior \\ Mestre em Ciências Contábeis (Universidade \\ Presbiteriana Mackenzie) \\ Mestrando em Direito Econômico, Financeiro e \\ Tributário (USP) \\ Consultor tributário da Secretaria da Fazenda-SP
}

\author{
José Carlos Tiomatsu Oyadomari \\ Doutor em Controladoria e Contabilidade \\ (FEA/USP) \\ Professor do Programa de Pós Graduação \\ Stricto Sensu em Ciências Contábeis da \\ Universidade Presbiteriana Mackenzie
}

\section{Resumo}

O presente artigo tem como objetivo a compreensão prática da adoção e contabilização da sistemática de tributação da substituição tributária do ICMS, e análise dos principais impactos desta forma de tributação na lucratividade e nos custos empresariais, tendo como contribuições: (i) aos empresários, a ampliação do conhecimento sobre os impactos da substituição tributária na lucratividade e nos custos empresariais; (ii) ao governo (e legisladores), o conhecimento de quais os efeitos deste tipo de tributação nos agentes econômicos empresariais; (iii) aos estudantes e pesquisadores, uma contribuição didática no conhecimento deste fenômeno, para que se possibilite o desenvolvimento de pesquisas futuras em entidades e setores econômicos. Em relação à metodologia, propõe a análise de casos didáticos simulados para o entendimento dos impactos financeiros da substituição tributária nas empresas, através da proposição de três modelos, desenvolvidos pelos autores com base na legislação tributária vigente. Após a análise de casos didáticos simulados, concluiu-se que com a utilização da técnica de substituição tributária do ICMS em determinados produtos e setores econômicos: (i) há aumento de custos tributários com diminuição da margem bruta das empresas deste setor econômico, quando a base de cálculo da substituição tributária for maior que o preço efetivo ao consumidor; (ii) há um desembolso antecipado, que afeta o fluxo de caixa e a necessidade de capital de giro e aumenta o custo financeiro e custo de oportunidade do capital das empresas; (iii) há um aumento da carga tributária, pela falta de "tratamento tributário diferenciado", para as empresas do Simples Nacional (microempresas e empresas de pequeno porte) que comercializem produtos sob a sistemática da substituição tributária. Ao final, três recomendações foram sugeridas pelos autores, com o intuito de aprimorar a legislação tributária nestes três aspectos: (i) a legislação tributária deve prever o ressarcimento da diferença do imposto pago a maior (se base de cálculo da substituição tributária for maior que o preço ao consumidor final praticado); (ii) a legislação deve prever prazos de pagamentos mais longos, que recomponham os prejuízos financeiros (para reequilibrar o fluxo de caixa e a necessidade de capital de giro das empresas); (iii) a legislação tributária deve atribuir um crédito fiscal especial aos microempresários (Simples Nacional) ou não deveria lhes ser aplicável a substituição tributária.

Palavras-chave: Substituição Tributária; ICMS; Custos Empresariais; Lucratividade; Contabilidade Tributária.

\section{Abstract}

This article aimed to understand the adoption of the ICMS-ST taxation method and its accounting, and examine his main impacts on profitability and business costs. This article had as contributions: (i) to firms: to know in depth about the main impacts of this taxation method on profits and business costs; (ii) to the government (and lawmakers): to know the effects of the introduction of this taxation method on the economic agents; (iii) to students and 
researchers: a didactic contribution to know this phenomenon, in order to facilitate the development of future research in companies and economic sectors. Regarding the methodology, this paper proposes the analysis of simulated teaching cases for understanding the financial impacts of the ST taxation method in companies, by proposing three models, developed by the authors based on the current tax legislation. After the analysis of simulated teaching cases, it was found that using the ICMS-ST taxation method on certain products and economic sectors leads to: (i) increased tax costs and reduced gross margins of companies in this economic sector (when the ICMS-ST taxable price is greater than the effective price to the consumer); (ii) early disbursement, which affects the cash flow and working capital needs and increases the financial cost and opportunity cost of capital of companies; (iii) increase the tax burden, because of the lack of "differential tax treatment" for companies SN (micro and small businesses) that sell products under the ICMS-ST taxation method. Finally, three recommendations were suggested by the authors for the purpose of improvement of tax legislation (ICMS-ST): (i) tax law should permit tax overpaid reimbursement (if ICMS-ST taxable price is greater than the effective price to the consumer); (ii) tax law should establish longer payment terms, to restructure the financial losses (to balance firms's cash flow and working capital needs); (iii) tax law should give a special tax credit to microentrepreneurs (SN) or should not apply to them the ICMS-ST taxation method.

Keywords: ST; ICMS; Business Costs; Profitability; Tax Accounting.

\section{INTRODUÇÃO}

Os governos estaduais atualmente estão ampliando o rol de produtos abarcados pela técnica de tributação da substituição tributária no ICMS, cujo funcionamento consiste no recolhimento do ICMS antecipadamente por um único contribuinte, geralmente o primeiro na cadeia de valor (em geral, o industrial - mercadoria nacional - ou importador - mercadoria importada -), para fins de diminuição da sonegação do imposto, facilidade de arrecadação e aumento de arrecadação.

O funcionamento essencial deste mecanismo consiste na fixação de um preço de venda determinístico pela legislação tributária (chamado de base de cálculo da substituição tributária, que consiste no preço final do produto estimado ao consumidor final), que serve como base para o recolhimento antecipado do ICMS - Substituição Tributária, já nas indústrias e importadores, chamados tecnicamente como "substitutos tributários". Diversos exemplos podem ser citados nas vinte e sete (27) Unidades Federativas Brasileiras, abrangendo diversos setores (apenas a título exemplificativo: bebidas, automotivos, cimento; fumo, sorvetes, pneumáticos e diversos outros produtos).

Por outro lado, no ambiente empresarial, a concorrência em alguns setores é bastante acirrada, sendo a margem de lucro bastante pressionada por fatores concorrenciais que podem levar a algumas oscilações e redução de preços em determinados períodos, na prática, difíceis de serem previstas pelo legislador ao fixar as bases de cálculo por substituição tributária.

Nas empresas sujeitas ao regime de substituição tributária, quando estas acabam por reduzir os preços efetivos de venda comparativamente aos fixados pela legislação tributária, esse mecanismo pode provocar diversos impactos financeiros na cadeia de valor (indústrias, atacadistas, varejistas), além dos efeitos financeiros de antecipação de pagamento do imposto inerentes à própria sistemática de tributação da substituição tributária, que faz com que o imposto (ICMS) seja temporalmente recolhido antes do percurso do produto por toda a cadeia produtiva e comercial.

Já em relação às empresas varejistas do Simples Nacional (microempresas e empresas de pequeno porte), tal sistemática de tributação de retenção antecipada do ICMS nas indústrias, acaba por eliminar o "tratamento tributário diferenciado e mais benéfico" 
atribuídos às microempresas e empresas de pequeno porte pela Constituição e pela legislação tributária em geral.

Apesar de todas estas evidências empíricas cientificamente ainda não comprovadas, em termos acadêmicos, e a despeito das inúmeras notícias, entrevistas e críticas realizadas pelas empresas e seus representantes na mídia nacional, a literatura acadêmica nacional é carente de estudos teóricos e práticos no tema da substituição tributária do ICMS, sendo que os estudos existentes basicamente focaram na análise de questões jurídicas, sem que houvesse estudos efetivos abordando os aspectos contábeis e econômicos práticos desta forma de tributação e seus impactos financeiros no custo das empresas e microempresas.

Desta forma, o presente artigo tem o objetivo de discutir a compreensão prática da tributação pela substituição tributária do ICMS, sua contabilização, e alguns de seus principais impactos na realidade empresarial, iniciando por uma releitura de alguns conceitos financeiros relacionados à lucratividade empresarial, procurando mostrar como tais conceitos tradicionais se relacionam com a sistemática de tributação da substituição tributária, para ao final, os autores proporem três modelos práticos sobre os impactos desta forma de tributação na lucratividade e nos custos empresariais, considerando: (i) a dificuldade da legislação tributária em prever o preço efetivo praticado ao consumidor final; (ii) o custo financeiro da antecipação do imposto na cadeia de valor; e (iii) a falta de "tratamento tributário diferenciado" para as empresas varejistas do Simples Nacional (Microempresas e Empresas de Pequeno Porte).

\section{Referencial Teórico}

O referencial teórico deste trabalho abrangerá: a) os conceitos jurídicos básicos de ICMS e de substituição tributária do ICMS; b) a contabilização do ICMS na modalidade de substituição tributária; c) o conceito de lucro e lucratividade e de alguns conceitos financeiros normalmente atrelados à lucratividade empresarial, procurando mostrar como tais conceitos se relacionam com a sistemática de tributação da substituição tributária: (i) margem bruta, (ii) necessidade de capital de giro e fluxo de caixa, (iii) custo financeiro; d) a formação dos preços considerando o ICMS substituição tributária.

\subsection{Noções Jurídicas de ICMS e de Substituição Tributária do ICMS}

\subsubsection{ICMS: aspectos gerais}

O ICMS está previsto diretamente na Constituição Federal (inciso II do artigo 155) sendo denominado de "imposto sobre operações relativas à circulação de mercadorias $e$ sobre prestações de serviços de transporte interestadual e intermunicipal e de comunicação, ainda que as operações e as prestações se iniciem no exterior". De forma resumida expõe-se: (i) suas características essenciais, (ii) seu fato gerador principal (circulação de mercadorias), (iii) contribuintes genéricos, (iv) base de cálculo geral, (v) alíquotas gerais.

O ICMS apresenta algumas características gerais importantes: a) ser um imposto de competência estadual; b) ser um imposto não-cumulativo, permitindo a compensação do que for devido em cada operação com o montante cobrado nas operações anteriores pelo mesmo ou por outro Estado; c) ser um imposto seletivo, ou seja, pelo princípio da seletividade, o imposto pode ser cobrado em função da essencialidade das mercadorias (possibilidade de alíquotas diferenciadas por tipo de mercadorias); d) ser o principal tributo indireto a incidir sobre operações com mercadorias (ao lado do IPI e das contribuições do PIS/COFINS federais), tendo como principais contribuintes empresas comerciais e industriais.

O principal campo de tributação do ICMS diz respeito às operações relativas à circulação de mercadorias: materialidade mais conhecida do imposto, atinente a todas as operações que importem na circulação de mercadorias. Por sua vez, o contribuinte genérico do ICMS é: 
"qualquer pessoa, física ou jurídica, que realize, com habitualidade ou em volume que caracterize intuito comercial, operações de circulação de mercadoria ou prestações de serviços de transporte interestadual e intermunicipal e de comunicação, ainda que as operações e as prestações se iniciem no exterior" (caput do artigo $4^{\circ}$ da Lei Complementar 87/1996).

Já em relação à base de cálculo do imposto (ICMS na sistemática normal) referente à circulação de mercadorias, sua base de cálculo mais usual nas operações com mercadorias compreende o valor da operação com mercadorias e todos os demais gastos acessórios necessários para a entrada da mercadoria no estabelecimento do adquirente, tais como seguro, frete e outras despesas.

As alíquotas do ICMS podem ser definidas de forma seletiva pelos Estados, atribuindo-se alíquotas menores para os produtos mais essenciais e alíquotas maiores para os produtos mais supérfluos. Normalmente os Estados mantêm uma alíquota interna geral aplicável igualmente a maioria dos produtos, que no Estado de São Paulo é de 18\% (e em alguns Estados é 17\% ou 19\%). As alíquotas nas operações interestaduais são definidas por resolução do Senado Federal, e em geral são de $12 \%$ ou de $7 \%$.

\subsubsection{Substituição Tributária do ICMS ("para frente"): Aspectos Gerais}

A substituição tributária (na modalidade chamada "para frente”) é um regime de apuração do ICMS, pelo qual a responsabilidade pelo imposto devido em relação às operações, é atribuída originalmente a outro contribuinte, antes da ocorrência do fato gerador. Exemplificando, Rosa (2009, p. 53-54) conceitua que

"a substituição tributária das operações subseqüente, também chamada de substituição para frente, ocorre quando, por exemplo, uma fábrica de cigarros, ao vender para o comerciante, debita o imposto normal sobre sua operação, mas também já calcula o imposto do comerciante, referente a operação subseqüente, cobra na nota fiscal, apura e declara separadamente o valor do imposto retido e recolhe ao Estado, como substituto".

Esta modalidade de tributação, que ocorre em relação às operações subseqüentes, é caracterizada pela atribuição a determinados contribuintes, chamados de contribuintes substitutos (normalmente o primeiro na cadeia de comercialização: o fabricante ou importador) da responsabilidade pelo pagamento do imposto incidente nas saídas subseqüentes com a mercadoria, até sua saída destinada a consumidor final.

A sistemática da Substituição Tributária tem previsão constitucional no parágrafo $7^{\circ}$ do artigo $150 \mathrm{da} C F / 88$. Por sua vez, a alínea " $b$ " do inciso XII do parágrafo $2^{\circ}$ do artigo 155 da Constituição Federal diz que cabe à lei complementar dispor sobre a substituição tributária do ICMS. A Lei Complementar que rege as disposições gerais do ICMS e dispõe sobre as regras gerais da substituição tributária aplicável a todos os Estados é a Lei Complementar 87/1996, conhecida por "Lei Kandir". O artigo 6 da Lei Complementar 87/1996 por sua vez prevê que a substituição tributária deve ser instituída pelas respectivas leis estaduais.

Os critérios de fixação da base de cálculo da substituição tributária têm por objetivo prever o preço final da mercadoria ao consumidor final. Para tanto são utilizadas algumas regras de fixação de base de cálculo que variam de produto a produto, e cujas regras gerais estão determinadas no artigo $8^{\circ}$ da Lei Complementar 87/1996.

Assim, via de regra, a base de cálculo do ICMS por substituição tributária pode ser estabelecida (art. $8^{\circ}$ da Lei Complementar 87/1996) através de: a) Margem de Valor Agregado sobre os custos de aquisição da mercadoria; b) Preço final a consumidor, único ou máximo, que seja fixado por órgão público competente; c) Preço final a consumidor sugerido pelo fabricante ou importador; d) Pesquisa de Preços no Mercado. De qualquer forma, o objetivo destas metodologias é de aferir por algumas técnicas qual o preço que será praticado ao consumidor final, de modo a adotar este preço previsto, como sendo base de cálculo para retenção antecipada do ICMS Substituição tributária. 
Na prática a indústria ou importador recolhe o imposto devido pelo produto, calculado sobre o preço final que chegará ao consumidor final (estimado pela legislação tributária), após todo o percurso da cadeia de valor. Assim, ocorre na prática uma antecipação do imposto, cobrado antes da ocorrência dos fatos geradores futuros (circulação das mercadorias nas etapas seguintes). Segue exemplo ilustrativo:

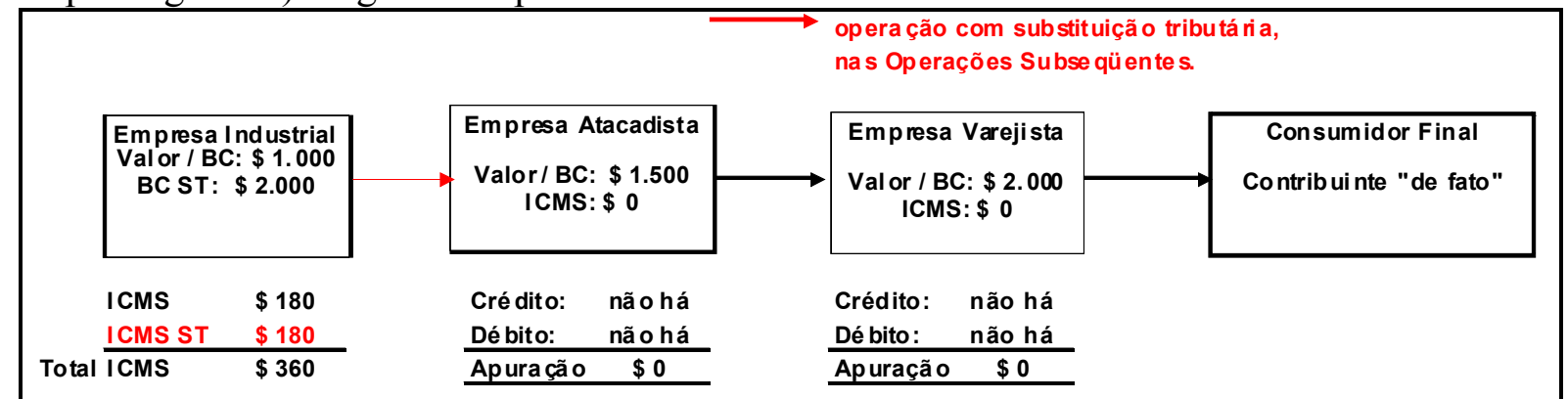

Figura 1: Substituição Tributária - venda da indústria para o atacadista, com base de cálculo ST (Preço de venda previsto ao consumidor final de $\mathrm{R} \$ 2.000,00)$, e valor de operação de $\mathrm{R} \$ 1.000,00$.

Desta forma, todas as etapas posteriores na cadeia de valor deste produto, serão realizadas pelos contribuintes substituídos (em geral, por comerciantes atacadistas e varejistas), que não terão mais que recolher nenhum imposto, uma vez que já foi recolhido na origem.

Todavia, como comumente o produto chega ao consumidor final, por um preço real distinto da base de cálculo da substituição tributária (estimada pelas regras da legislação fiscal), surgem importantes conflitos jurídicos entre o fisco e os contribuintes, questionandose o correto cálculo do imposto, e se a tributação é definitiva ou não, e se haveria o eventual direito de ressarcimento de diferenças pagas a maior.

Para entender esta problemática, o exemplo anterior é refeito, admitindo-se agora que o varejista no momento de sua operação final ao invés de adotar o preço previsto (pelos cálculos da legislação tributária), e usado como base de retenção, de R $\$ 2.000,00$, deu um desconto e vendeu a mercadoria ao consumidor final por $\mathrm{R} \$ 1.800,00$ :

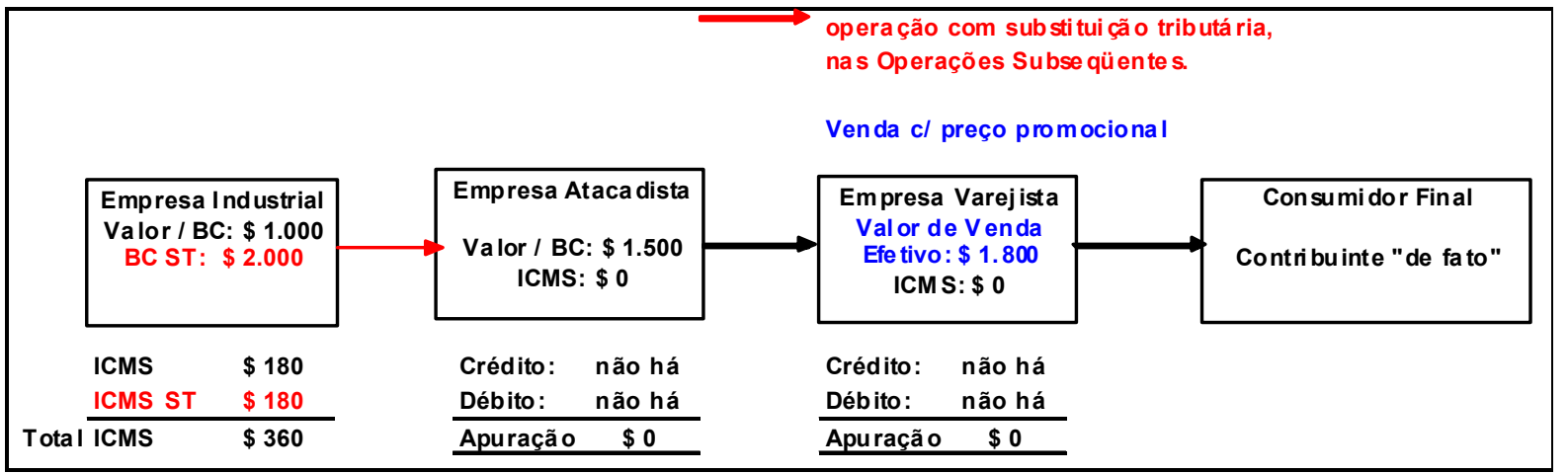

Figura 2: Substituição Tributária - "Preço de Venda Efetivo menor que a Base de Cálculo -ST"

A Constituição, embora assegure "a imediata e preferencial restituição da quantia paga, caso não se realize o fato gerador presumido" ( $\S 7^{\circ}$ do artigo 150 da Constituição Federal), não deixa claro se a restituição é cabível nos casos em que o preço de venda ao consumidor final é menor do que a base de cálculo da substituição tributária.

Atualmente o posicionamento no Supremo Tribunal Federal (precedente: ADIN n. ${ }^{\circ}$ 1.851-4/AL) é de que não caberia o ressarcimento do imposto no caso de venda a preço menor ou complemento do imposto no caso de preço a maior, considerando o fato gerador do ICMS substituição tributária - como definitivo. O ressarcimento só ocorreria em situações que o fato 
gerado não ocorreu ou vem a ocorrer em outro Estado (exemplos: quebra de estoque, perecimento, venda interestadual de produto que já teve o imposto retido no Estado de origem).

\subsection{Contabilidade Tributária: Contabilização do ICMS - Substituição Tributária X ICMS na Sistemática RPA - Normal}

A Contabilidade Tributária tem por conceito ser o "ramo da contabilidade aplicada, cujo objetivo é adequar as demonstrações financeiras contábeis e a legislação tributária" e tem por objeto "apurar e demonstrar os resultados econômicos (contábeis) com exatidão, conciliando o cálculo dos tributos com os parâmetros fixados pela legislação tributária". (FABRETTI, 2003, p.33)

O objetivo neste ponto é demonstrar como a sistemática de tributação da substituição tributária do ICMS afetaria as demonstrações contábeis (Balanço Patrimonial, Demonstração de Resultado, Demonstração de Valor Adicionado), fazendo-se um comparativo da contabilização normal do ICMS (regime RPA de débito e crédito) com a contabilização do ICMS na sistemática da substituição tributária.

Sabe-se que na contabilidade tributária tradicional do ICMS (em sua forma de apuração normal -RPA), são gerados créditos ao adquirente (princípio da nãocumulatividade). Desta forma, numa venda da indústria ao comércio de um produto no valor de $\mathrm{R} \$ 1.000,00$ (que posteriormente será revendido por $\mathrm{R} \$ 1.500,00$ ) e alíquota de ICMS de $18 \%$, a contabilidade tributária do adquirente, deverá registrar em estoques o valor de $\mathrm{R} \$$ 820,00 e reconhecer um crédito de ICMS de $\mathrm{R} \$ 180,00$, conforme figura e quadro exemplificativos abaixo:

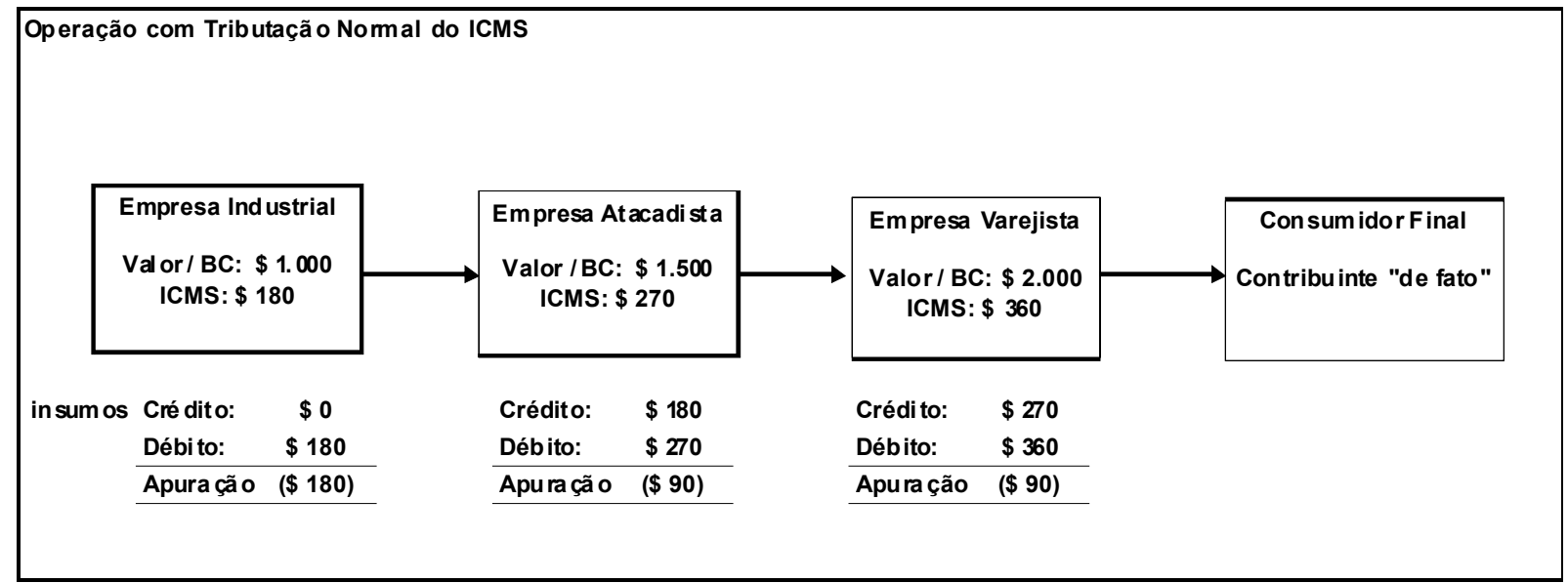

Figura 3: Operação Normal do ICMS: débitos e créditos

a) Indústria: (i) registra o valor total da NF de venda (Debita Caixa/Bancos de R\$ 1.000 e Credita Receita de Venda de \$1.000); ii) registro de despesa de ICMS (Debita Despesa ICMS Próprio de R\$ 180 e Credita ICMS a Pagar);

b) Comerciante: na aquisição: (i) registra aquisição da mercadoria como Estoque de $\$$ 820 e Crédito de ICMS de $\$ 180$ (Debita Estoque de $\$ 820$, Debita ICMS a Compensar de $\$ 180$ e Credita Caixa/Bancos de \$1.000); na venda a posterior: registra venda de \$1.500 (Debita Caixa/Bancos e Credita Receita de Vendas); (ii) registro de Despesa de ICMS (Debita Despesa ICMS Próprio de R\$270 e Credita ICMS a Pagar de R\$270); (iii) Baixa Estoque (Debita CMV e Credita Estoque em \$ 820); (iv) Compensa o ICMS a pagar com o crédito de ICMS (Credita ICMS a Compensar de $\$ 180$ e Debita ICMS a pagar de $\$ 180$, restando saldo de $\$ 90$ a recolher). 
*OBS.: veja que o adquirente tem direito ao crédito de ICMS das mercadorias adquiridas de $\$ 180$ para abater do ICMS devido em suas vendas de \$270, pagando efetivamente $\$ 90$.

Quadro 1: Quadro da Contabilização do ICMS Normal - RPA: Venda da Indústria ao Atacadista

Por sua vez, na sistemática de tributação do ICMS pela substituição tributária, se o produto for vendido por R $\$ 1.000,00$ sendo: a) R $\$ 180,00$, por dentro, do ICMS na operação própria; b) + R \$180,00 de ICMS - Substituição Tributária (por fora), totalizando um valor total de nota fiscal de R $\$ 1.180,00$; o adquirente (comerciante) terá que registrar todo o ICMS (próprio e ST) como custo, ou seja, fazer o registro de estoques de $\mathrm{R} \$ 1.180,00$, já que não terá nenhum crédito a ser utilizado na operação seguinte (mas em contrapartida, não terá mais nenhum imposto de ICMS a pagar nas operações seguintes).

Apresenta-se para o mesmo exemplo acima, figura e quadro exemplificativos abaixo:

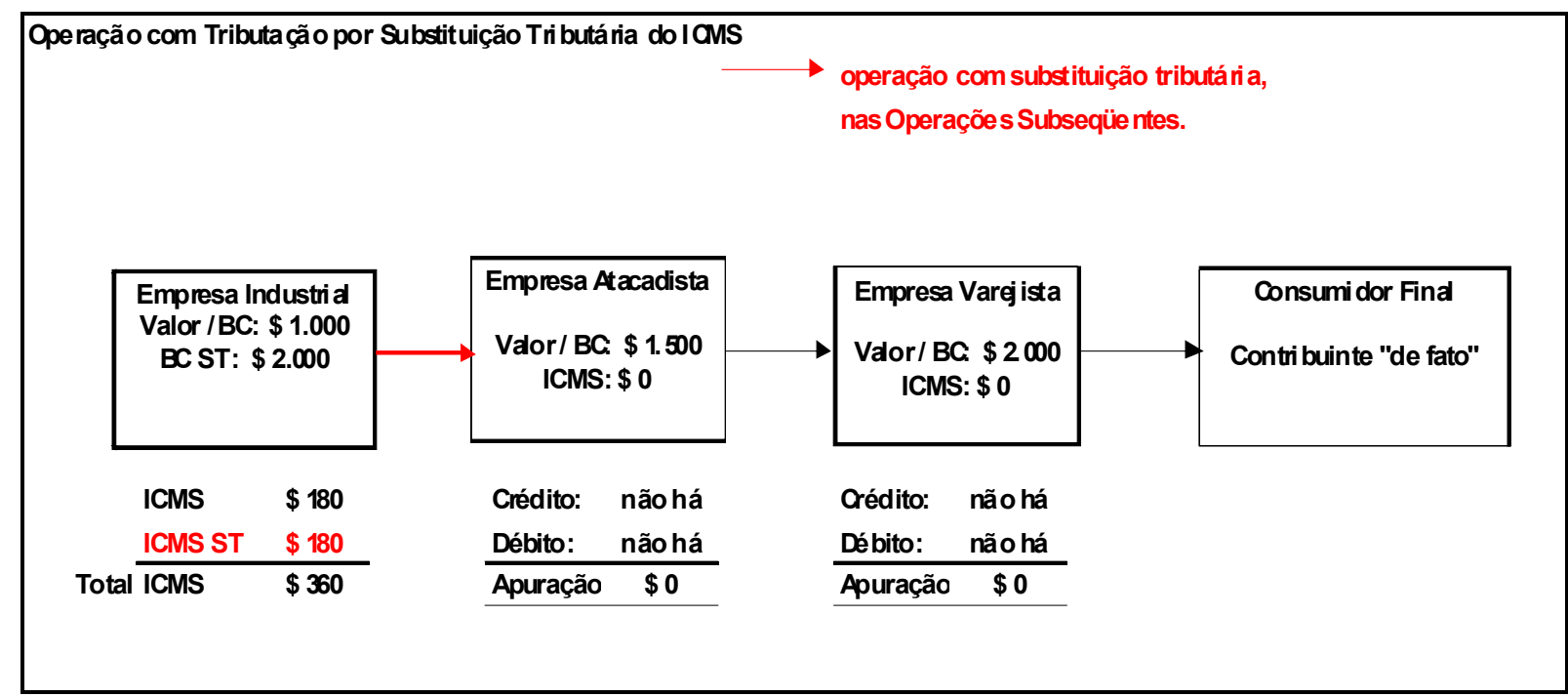

Figura 4: Operação com Substituição Tributária do ICMS: não há créditos aos adquirentes

a) Indústria: (i) registra o valor total da NF de venda mais ICMS-ST (Debita Caixa/Bancos de R\$ 1.180 e Credita Receita de Venda de \$ 1.000 e Credita ICMS SUBSTITUIÇÃO a Recolher de \$180); ii) registro de despesa de ICMS (Debita Despesa ICMS Próprio de R\$ 180 e Credita ICMS a Pagar); $\underline{\mathbf{O U}}$

(i) registra o valor total da NF de venda no resultado (Debita Caixa/Bancos de R\$ 1.180 e Credita Receita de Venda de \$ 1.180); ii) registro de Despesa de ICMS e ICMS-ST (Debita Despesa ICMS Próprio de R\$180 e Credita ICMS a Pagar e em seguida, e Debita Despesa ICMS-ST de \$ 180 e Credita ICMS SUBSTITUIÇÃO a Recolher);

b) Comerciante: na aquisição: (i) registra custo de mercadoria de $\$ 1.180$ (Debita Estoque e Credita Caixa/Bancos); na venda a posterior: registra venda de $\$ 1.500$ (Debita Caixa/Bancos e Credita Receita de Vendas); (ii) Baixa Estoque (Debita CMV e Credita Estoque em \$1.180).

*OBS.: veja que o adquirente não tem nenhum crédito de ICMS mas também nenhum débito de ICMS adicional.

Quadro 2: Quadro da Contabilização do ICMS-ST ( "para frente”): Venda da Indústria ao Atacadista

Segundo Ariovaldo do Santos (2007, p.185) "existem diversas alternativas para a contabilização do ICMS em regime de substituição tributária (...) entretanto, (...) apenas as duas que são mais utilizadas e aceitas no Brasil". No exemplo acima, foram apresentadas as 
duas principais formas de contabilização do contribuinte substituto, e a forma de contabilização do contribuinte substituído.

A grande diferença para o contribuinte substituto entre a primeira alternativa e a segunda alternativa está na inclusão ou não do ICMS recolhido segundo o regime de substituição tributária no valor do faturamento bruto.

Esta diferença entre estas duas formas de contabilização, com exceção do Balanço Patrimonial (que em ambas hipóteses permanece o mesmo), implica em algumas diferenças nas demonstrações financeiras: a) na Demonstrações de Resultado: (i) havendo a inclusão da ST no faturamento bruto, deverá aparecer a conta dedutora de "ICMS-ST" (compreendida entre as contas de impostos sobre vendas), ou (ii) já se registrará o faturamento sem a inclusão do valor pago a título da ST, não havendo então necessidade desta conta dedutora entre as contas de impostos sobre vendas; b) na Demonstração de Valor Adicionado: (i) havendo a inclusão da ST nas receitas de vendas de mercadoria, deverão os valores de ICMS-ST serem considerados nos "impostos, taxas e contribuições" para fins de distribuição do valor adicionado, ou (ii) já se registrará as receitas de vendas de mercadoria sem a inclusão do valor pago a título da ST, não devendo então os valores de ICMS-ST serem considerados nos "impostos, taxas e contribuições" para fins de distribuição do valor adicionado. (SANTOS, 2007, p.187)

Logo, como se vê, o ICMS próprio e o ICMS-ST, quando da adoção da sistemática da substituição tributária, se transformam ambos em custos ao adquirente da mercadoria (no exemplo, do atacadista que adquire do industrial), sendo portanto, o custo de tais tributos incorporados diretamente aos estoques, quando da aquisição, e depois lançados como CMVCusto da Mercadoria Vendida, quando da venda futura. Por outro lado, os adquirentes (atacadistas e varejistas) não terão mais despesas com o recolhimento do ICMS em suas operações.

\subsection{Conceitos de Lucro e Lucratividade}

O presente artigo analisa os efeitos financeiros na lucratividade e nos custos das empresas e microempresas, que são tributadas pela substituição tributária do ICMS. Portanto, inicialmente é abordado o conceito de "lucro" e "lucratividade" e sua importância para as empresas, para em seguida, eleger-se alguns conceitos financeiros que serão adotados como parâmetro de "lucratividade".

De acordo com Hendricksen e Van Breda (1999, p.207-208):

"um dos principais objetivos da empresa é a maximização do fluxo de dividendos aos acionistas ao longo de toda a vida da empresa, ou a maximização do valor de liquidação ou valor de mercado da empresa, ao final de sua vida, ou em pontos intermediários (...) Contudo, os objetivos mais comuns da mensuração do lucro exigem mensurações em periodos mais curtos, para facilitar o controle e a tomada de decisão por acionistas, credores e administradores em bases contínuas ou periódicas".

Assim, Hendricksen e Van Breda (1999, p.181) traçam um conceito de lucro:

"Os contadores freqüentemente referem-se a dois conceitos econômicos, baseados na observação da realidade, como pontos de partida lógicos para a definição de um conceito de lucro em termos contábeis. Esses dois conceitos econômicos são a variação da riqueza e a maximização de lucro sob condições especificadas de estrutura de mercado, demanda de produtos e custos de fatores de produção. Esses conceitos estão implícitos nas declarações do Fasb no sentido de que:

O Lucro no sentido amplo, é a variação do patrimônio de uma empresa durante um período (...)

O teste do sucesso (ou insucesso) das operações de uma empresa é a medida pela qual o dinheiro é obtido é superior (ou inferior) ao dinheiro gasto (investido) no longo prazo.

$O$ primeiro é o conceito de preservação do capital, e o último é uma versão do conceito de maximização de lucro".

Por sua vez, o conceito de "lucratividade" está tradicionalmente atrelado a um percentual obtido pela razão entre o lucro e outra medida patrimonial (do balanço) ou da demonstração de resultados, tais como: investimentos, patrimônio líquido ou receita bruta. 
Assaf Neto (2006, p.238 e 262), por exemplo, define o Retorno sobre Investimento (ROI) como sendo calculado pela fórmula ROI = Lucro Operacional / Investimento, e o Retorno sobre o Ativo (ROA) pela fórmula ROA = Lucro Operacional / (Ativo Total - Lucro Líquido do próprio exercício). Por sua vez, a "lucratividade" também pode ser medida em relação à "receita de vendas" do período, sendo que normalmente isto é feito por meio de uma análise vertical do balanço, onde se atribui a base de $100 \%$ às receitas brutas de vendas.

Logo, percebe-se, que o lucro é um objetivo essencial para as empresas, e a maximização da lucratividade significa que a empresa pode conseguir obter mais lucro com um determinado nível de recursos.

\subsection{Conceitos Financeiros atrelados à Lucratividade das Empresas e suas Relações com a Sistemática de Substituição Tributária no ICMS}

O objetivo neste ponto do artigo é partir de alguns conceitos de finanças e contabilidade, para demonstrar teoricamente como estes conceitos atrelados à "lucratividade empresarial" poderiam ser afetadas em face da adoção da técnica de tributação (substituição tributária do ICMS).

\subsubsection{Margem Bruta e o ICMS - Substituição Tributária}

A análise de "margem bruta" é uma das mais tradicionais em finanças e contabilidade, consistindo na análise da variação da razão em percentual do lucro bruto contábil sobre a receita bruta contábil, em diferentes períodos. Para se fazer este cálculo dentro do critério de elaboração das demonstrações de resultado, se parte da receita bruta de vendas, fazendo-se as deduções, dentre estas dos impostos sobre vendas, e após a obtenção da receita líquida, se faz a dedução do custo das mercadorias ou de produção, para se chegar então ao Lucro Bruto.

São conceitos contábeis fundamentais. A "Receita Bruta é o total bruto vendido no período. Nela estão inclusos os impostos sobre vendas (os quais pertencem ao governo) e dela não foram subtraídas as devoluções (vendas canceladas) e os abatimentos (descontos) ocorridos no período". Os "impostos e taxas sobre vendas são aqueles gerados no momento da venda; variam proporcionalmente à venda, ou seja, quanto maior for o total de vendas, maior será o imposto. (...) Na verdade, os impostos sobre vendas não pertencem à empresa, mas ao governo. Ela é uma mera intermediária que arrecada impostos junto ao consumidor e recolhe ao governo; por isso, não devem ser considerados como receita real da empresa". Após estas deduções dos impostos sobre vendas das devoluções e dos descontos, é que se chega na rubrica da Receita Líquida. O "Lucro Bruto é a diferença entre a venda de mercadorias e o custo dessa mercadoria vendida, sem considerar despesas administrativas, de vendas e financeiras. (...)". (conceitos e adaptações de IUDÍCIBUS, 1998).

Como se vislumbra na prática, a análise da variação das margens brutas é muito usada numa abordagem econômico-financeira de análise de desempenho empresarial tradicional. Em Govindarajan (2006), por exemplo, o autor repassa as principais análises tradicionais de variações financeiras feitas em relatórios de desempenho financeiro das empresas, reconhecendo também a importância da análise da "margem bruta". Olhando para uma empresa industrial, define que "margem bruta é a diferença entre o preço real de venda e o custo-padrão de produção. $O$ custo-padrão de produção em vigor deve levar em conta modificações ocorridas nos custos de produção causadas por alterações de salários e de custos dos materiais"”. (GOVINDARAJAN, 2006).

O conceito de análise de margem bruta neste artigo deve se relacionar com os efeitos da adoção da técnica de tributação (substituição tributária) do ICMS, principal imposto sobre vendas, nas deduções dos impostos sobre vendas e no custo das mercadorias vendidas. $\mathrm{Na}$ verdade, a mudança de critério de apuração do imposto, e sua antecipação, alteram o custo das mercadorias adquiridas pelos adquirentes da cadeia de valor, de modo que o imposto pago 
antecipadamente pela primeira empresa da cadeia (no geral, industrial ou importador), se torna custo da mercadoria para os adquirentes seguintes (atacadistas e varejistas, no geral).

Isto porque na contabilidade tributária tradicional, o ICMS em sua forma de apuração normal, é um crédito para o adquirente. Assim, numa venda da indústria ao comércio de um produto no valor de $\mathrm{R} \$ 100,00$ e alíquota de ICMS de $18 \%$, a contabilidade do adquirente, deverá registrar em Estoques o valor de $\mathrm{R} \$ 82,00$ e reconhecer um Crédito de ICMS de R \$18,00. Já na sistemática de tributação do ICMS pela substituição tributária, se o produto for vendido por $\mathrm{R} \$ 100,00$ (sendo $\mathrm{R} \$ 18,00$, por dentro, do ICMS na Operação Própria) + R \$18,00 de ICMS - Substituição Tributária (por fora), totalizando um valor total de nota fiscal de R $\$ 118,00$, o adquirente (comerciante) terá que registrar tudo como custo, ou seja, fazer o registro de Estoques de $\mathrm{R} \$ 118,00$, já que não terá nenhum crédito a ser utilizado na operação seguinte (em contrapartida, não terá mais nenhum ICMS a pagar nas operações seguintes). Logo, sendo os valores dos Estoques maiores, quando do momento da venda, haverá necessariamente um maior reconhecimento de Custo de Mercadoria Vendida, quando da baixa contábil destes estoques. Esta forma de contabilização da substituição tributária é também confirmada por Pegas (2007, p. 133-135).

No caso ainda, da tributação ser superestimada (acima dos valores praticados ao consumidor final), tal técnica de tributação poderá em tese, diminuir as margens brutas praticadas naquele setor ou daquele produto, principalmente quando o eventual aumento de custo não pode ser repassado aos adquirentes e consumidores.

\subsubsection{Necessidade de Capital de Giro / Fluxo de Caixa e o ICMS - Substituição Tributária}

Inicialmente, pela definição contábil, o capital de giro (líquido) é obtido pela diferença entre o ativo circulante e o passivo circulante ou pela subtração da soma do patrimônio líquido com o exigível a longo prazo da soma do ativo permanente com o realizável a longo prazo. Segundo Assaf Neto (2006, p.170):

"o conceito de capital circulante líquido apresenta-se mais claramente identificado como o 'excedente das aplicações a curto prazo (em ativo circulante) em relação às captações de recursos processadas também a curto prazo (passivo circulante)'”. "Em suma, o capital circulante líquido é o volume de recursos a longo prazo (permanentes) da empresa que se encontra aplicado no ativo circulante, devendo por conseguinte gerar condições de sustentação e crescimento em suas atividades".

Já conceitualmente:

"o fluxo de caixa é um instrumento que relaciona ingressos e saídas (desembolsos) de recursos monetários no âmbito de uma empresa em determinado intervalo de tempo. A partir da elaboração do fluxo de caixa é possível diagnosticar eventuais excedentes ou escassez de caixa, determinando-se medidas saneadoras a serem tomadas". (ASSAF NETO, 2002)

Os conceitos de "necessidade de capital giro" e "fluxo de caixa" para este artigo, visam analisar se a antecipação do imposto na sistemática de tributação pela substituição tributária afetaria o custo de oportunidade (custo de capital) das empresas. Para entendimento, observa-se este exemplo hipotético, onde cada um dos três contribuintes pagava \$10 de ICMS:

\section{Quadro 3 - Fluxo de Caixa dos pagamentos tributários (ICMS normal x ICMS-ST)}

\section{Situação 1: Tributacão normal do ICMS}

Industrial: recolhe $\$ 10$ no momento de sua venda para o atacadista Atacadista: recolhe $\$ 10$ no momento de sua venda para o varejista Varejista: recolhe $\$ 10$ no momento de sua venda para o consumidor final

\section{Situação 2: Substituição Tributária do ICMS}

Industrial: recolhe $\$ 30$ no momento de sua venda para o atacadista 
Atacadista: não recolhe nada no momento de sua venda para o varejista

Varejista: não recolhe nada no momento de sua venda para o consumidor final

Percebe-se claramente que a introdução da técnica de tributação por substituição tributária, faz com que o governo receba antecipadamente todo o ICMS, que seria recolhido em cada etapa da cadeia de valor do produto. Ou seja, na prática, as empresas adiantam o valor de todo o imposto que seria obtido até o produto chegar ao consumidor final, "financiando", portanto, o governo. Observa-se que como o dinheiro tem valor no tempo, o fato das empresas pagarem antecipadamente, implicará numa redução de suas disponibilidades de curto prazo, o que gerará um custo de oportunidade para as empresas (juros financeiros adicionais que a empresa terá para financiar suas atividades).

Em Matarazzo (1998, p.344) a fórmula de necessidade de Capital de Giro é "NCG = ACO - PCO" onde: ACO é considerado como Ativo Circulante Operacional e PCO como Passivo Circulante Operacional. Sendo que se a empresa tiver um PCO maior que o ACO, a mesma neste caso não teria uma NCG em virtude da mesma estar sendo financiada por terceiros, ou seja, a mesma terá NCG real quando o seu ACO for maior que o seu PCO.

Logo, se a empresa estiver sujeita à substituição tributária e for contribuinte substituído (ou seja, já comprar o produto com o imposto retido - normalmente o caso do atacadista e varejista que compram da indústria), a empresa pode vir notadamente a ter a NCG aumentada em virtude dos pagamentos dos impostos antecipados, exceto se o fornecedor repassar totalmente no custo o adiantamento dos impostos, conforme o exemplo prático da tabela abaixo:

Empresa substituída sem substituição tributária e com substituição tributária (com e sem aumento de custos dos fornecedores fabricantes).

\section{Situação I: Empresa sem Substituição Tributária}

(A Receber + Estoques) - (Fornecedores + Salários + Impostos)

$(4.000,00+6.000,00)-(4.500,00+2.000,00+500,00)$

$\mathrm{NCG}=10.000,00(-) 7.000,00$

$\mathrm{NCG}=3.000,00$ (Obs: antes da venda da mercadoria a NCG é 2.500, por causa dos impostos)

Situação II: Empresa com Substituição Tributária c/ aumento do custo dos fornecedores

(A Receber + Estoques) - (Fornecedores + Salários + Impostos)

$(4.000,00+6.000,00)-(5.000,00+2.000,00+00,00)$

$\mathrm{NCG}=10.000,00(-) 7.000,00$

$\mathrm{NCG}=3.000,00$

Situação III: Empresa com Substituição Tributária s/ aumento do custo dos fornecedores

(A Receber + Estoques) - (Fornecedores + Salários + Impostos)

$(4.000,00+6.000,00)-(4.500,00+2.000,00+00,00)$

$\mathrm{NCG}=10.000,00(-) 6.500,00$

$\mathrm{NCG}=3.500,00$

Quadro 4: Substituição Tributária - Efeitos na Necessidade de Capital de Giro (NCG)

No exemplo acima, o fornecedor industrial vendia a mercadoria por $\$ 4.500$, e com a introdução da substituição tributária passa a ter um custo adicional de $\$ 500$ (referente à substituição tributária, que em tese corresponde ao imposto que o adquirente deveria pagar quando de sua venda futura), podendo na maioria dos casos, o fornecedor aumentar o seu preço da mercadoria para $\$ .5000$ (repasse total do ICMS-ST), afetando no primeiro momento o capital de giro da empresa comercial (substituída) adquirente. 


\subsubsection{Custo Financeiro, Custo de Oportunidade do Capital da Empresa e o ICMS - Substituição Tributária}

Segundo Atkinson (2000, p. 534), custo de capital é o retorno que a empresa deve ganhar sobre seus investimentos para satisfazer o retorno de seus investidores. Para Assaf Neto (2003, p. 355) o custo de capital de uma empresa reflete, em essência, a remuneração mínima exigida pelos proprietários de suas fontes de recursos (credores e acionistas).

Basicamente, o custo de capital pode ser decomposto em custo de capital de terceiros (tais como os obtidos com empréstimos em instituições financeiras, ou na emissão de títulos de dívida) e o custo de capital próprio (formado pela integralização de capital dos sócios ou emissão de ações, bem como os re-investimentos dos lucros gerados pela empresa).

Quando a empresa aumenta sua necessidade de capital giro, para fazer frente ao pagamento das despesas correntes de sua atividade, entre estas incluídas os impostos sobre vendas (no caso o ICMS - Substituição Tributária, que antecipa na indústria o pagamento do ICMS que será devido na cadeia comercial subseqüente), as empresas da cadeia estão recolhendo o imposto, em um momento anterior ao que normalmente seria recolhido na forma de tributação do ICMS normal, gerando, portanto, um custo financeiro resultante da aplicação do percentual do Custo de Capital da empresa pelo valor do imposto que foi antecipado.

Abaixo demonstra-se um exemplo, fazendo um comparativo do custo financeiro entre uma operação normalmente tributada pelo ICMS e uma operação tributada pelo ICMS Substituição Tributária na indústria, na qual:

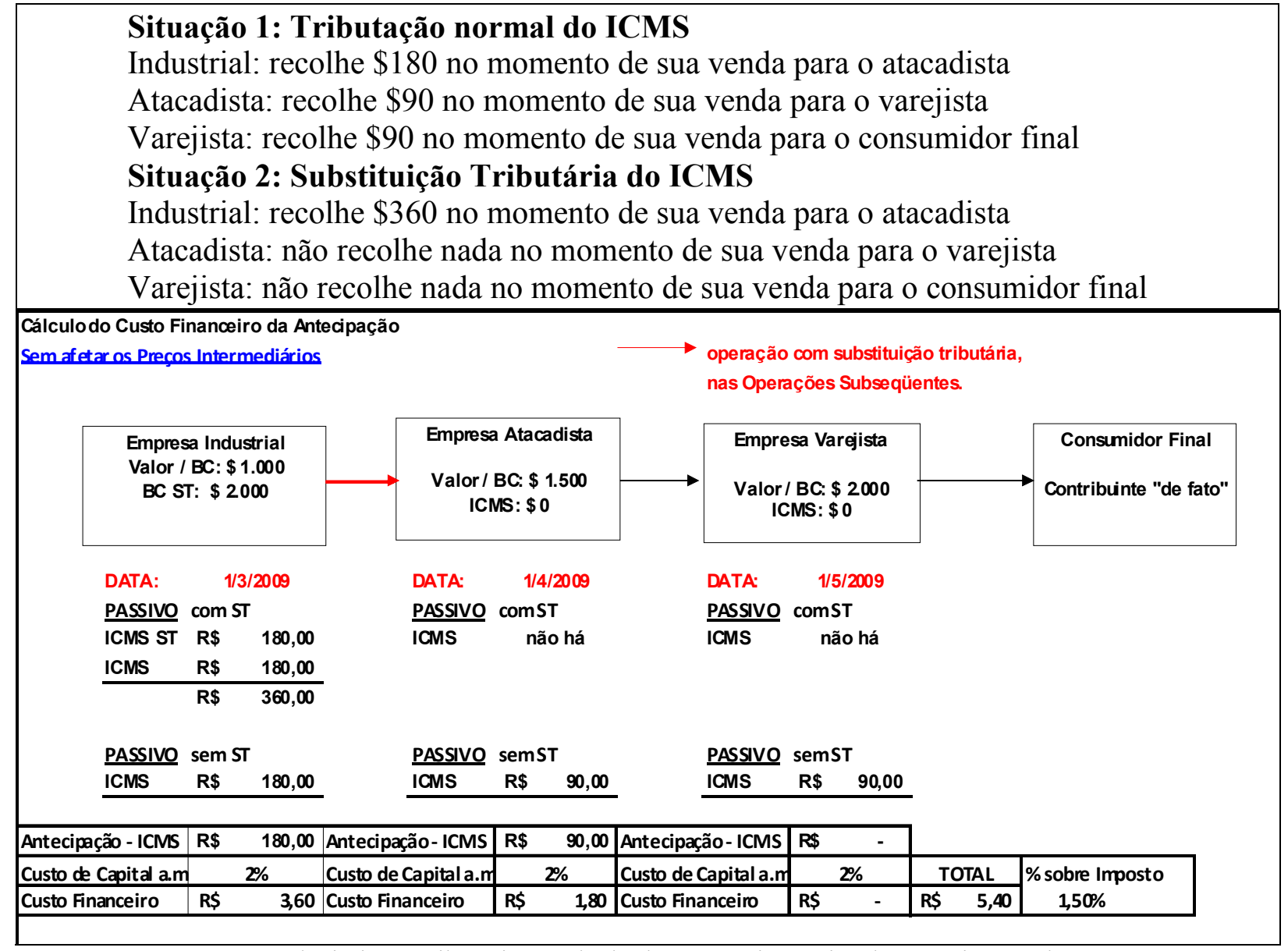

Figura 5: Substituição Tributária - Cálculo do Custo Financeiro da Antecipação do ICMS 


\subsection{Formação de Preços e o ICMS - Substituição Tributária}

O preço é um importante elemento para a determinação da lucratividade da empresa. Sua importância se justifica, porque os "preços praticados nos mercados devem ser suficientemente capazes de remunerar os custos plenos, gerar margem razoável de lucro e cobrir todos os impostos incidentes, que podem ser de três diferentes esferas - federal, estadual e municipal - e de dois tipos básicos - cumulativos e não cumulativos". (BRUNI \& FAMÁ, 2004, p.299)

O objetivo aqui é demonstrar que os custos dos impostos são repassados de alguma forma ao preço dos produtos. Neste exemplo, visa-se destacar especialmente o ICMS e o ICMS- Substituição Tributária. Assim, apresentam-se alguns exemplos adaptados (Assef, 2002, p.105-106) da formação dos preços nas vendas da indústria para ao atacado e varejo:

a) Fabricante vendendo para Distribuidor, que revenderá para varejista (todos do mesmo Estado)

Tabela 1: FORMAÇÃO DE PREÇOS: venda fabricante ao distribuído atacadista.

Preço de venda do fabricante $=\mathbf{R} \$ \mathbf{8 0 , 0 0}$

Preço de venda do distribuidor $=\mathrm{R} \$ 100,00$

Preço sugerido ao varejista (base de cálculo da substituição) $=\mathrm{R} \$ 135,00$

Base de cálculo do ICMS (operação própria) $=\mathrm{R} \$ 80,00$

ICMS próprio $(\mathrm{R} \$ 80,00 \times 18 \%$ alíquota $)=\mathrm{R} \$ 14,40$

Base de Cálculo da Substituição Tributária $=\mathrm{R} \$ 135,00$

ICMS - Substituição Tributária - (Base ST x alíquota) - ICMS próprio $=\mathrm{R} \$$ $135,00 \times 18 \%-\mathrm{R} \$ 14,40=\mathrm{R} \$ 9,90$

Total da Nota Fiscal $/$ Preço Total $=\mathbf{R} \$ 89,90$

b) Fabricante vendendo para Varejista (ambos do mesmo Estado)

Tabela 2: FORMAÇÃO DE PREÇOS: venda fabricante ao varejista.

Preço de venda do fabricante $=\mathbf{R} \$ \mathbf{1 0 0 , 0 0}$

Preço sugerido ao varejista (base de cálculo da substituição) $=\mathrm{R} \$ 135,00$

Base de cálculo do ICMS (operação própria) $=\mathrm{R} \$ 100,00$

ICMS próprio $(\mathrm{R} \$ 100,00 \times 18 \%$ alíquota $)=\mathrm{R} \$ 18,00$

Base de Cálculo da Substituição Tributária $=\mathrm{R} \$ 135,00$

ICMS - Substituição Tributária - (Base ST x alíquota) - ICMS próprio $=\mathrm{R} \$$ $135,00 \times 18 \%-\mathrm{R} \$ 18,00=\mathrm{R} \$ 6,30$

Total da Nota Fiscal $/$ Preço Total $=$ R\$ 106,30

$\mathrm{Na}$ verdade, estes exemplos acabam pressupondo que o valor do ICMS-ST será totalmente repassado às empresas subseqüentes da cadeia comercial. Este é teoricamente o objetivo, já que o ICMS - Substituição Tributária é tecnicamente o imposto devido pelos próximos "players" da cadeia comercial.

Todavia, somente a demonstração empírica de cada caso específico da realidade empresarial pode demonstrar se a formação de preços se dá desta forma. Isto porque a política de preços depende das condições competitivas e comerciais de cada mercado. 


\section{METODOLOGIA POR ANÁlISE DE CASOS DIDÁTICOS SIMULADOS: MODELOS DOS IMPACTOS DA SUBSTITUIÇÃO TRIBUTÁRIA NA LUCRATIVIDADE E NOS CUSTOS EMPRESARIAIS}

Após a exposição de bases teóricas, se passa à análise dos impactos financeiros da adoção desta técnica de tributação (substituição tributária do ICMS) na lucratividade e nos custos empresariais, através da proposição de modelos práticos e embasados em estudo de casos simulados, desenvolvidos pelos autores deste artigo, considerando a legislação tributária vigente. Logo, os modelos práticos que abaixo se apresentam, refletem a interpretação econômico-contábil da legislação tributária vigente, de forma inovadora, e não se encontram na referência bibliografia atual sobre este assunto. Basicamente desenvolvem-se três modelos traçados com base em algumas situações embasadas na legislação tributária vigente:

\subsection{Modelo I: Cálculo do Efeito Financeiro da Antecipação do Imposto (ST) na Cadeia Econômica de Valor do Produto:}

Inicialmente se observa como seria a tributação pela sistemática normal do ICMS, estimando-se hipoteticamente a data das vendas (fatos geradores) do ICMS em cada etapa da cadeia:

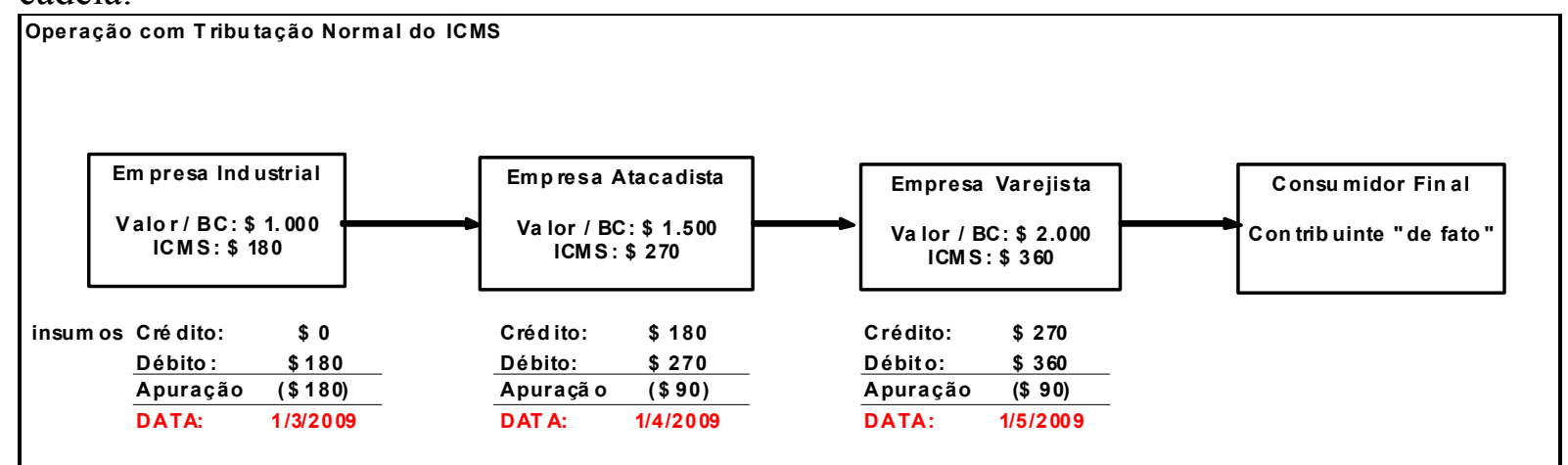

Figura 6: Tributação Normal do ICMS

Tendo em vista a sistemática de tributação do ICMS por substituição tributária, o imposto passa a ser recolhido antecipadamente já na $1^{\mathrm{a}}$ etapa conforme novo gráfico, usandose no cenário a premissa de que os "preços intermediários" não são afetados, e desconsiderando-se os prazos de pagamento do imposto previstos na legislação de cada Estado:

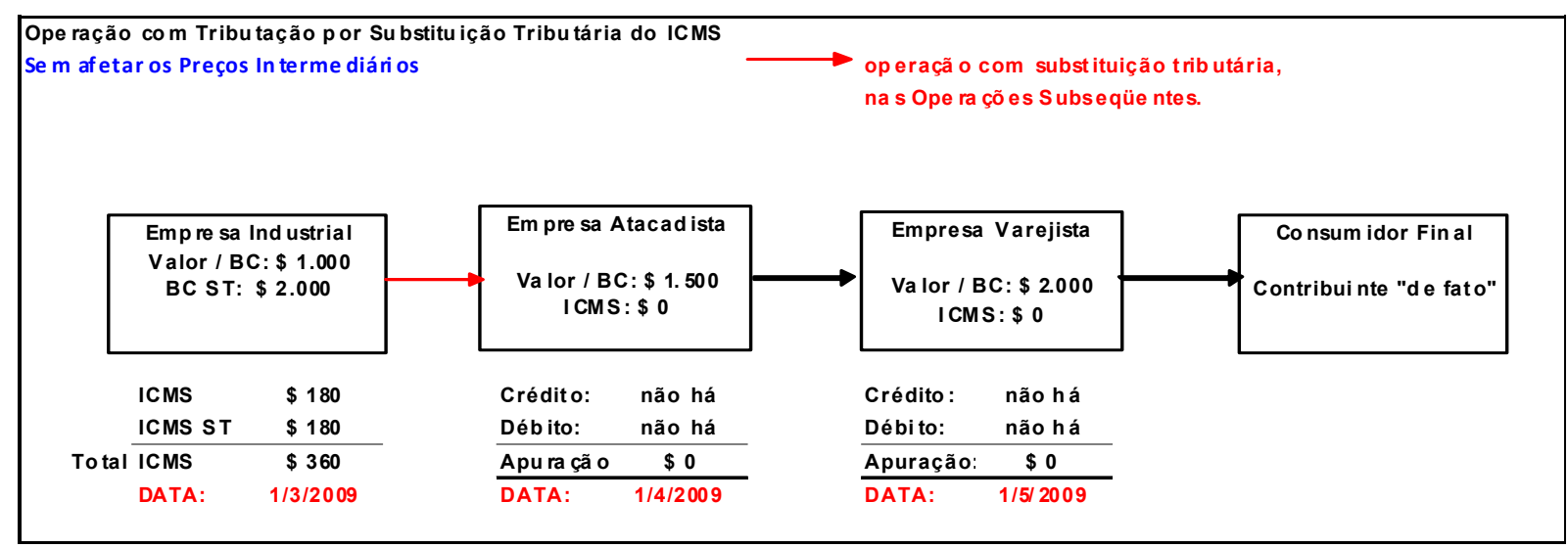

Figura 7: Tributação por Substituição Tributária do ICMS

Todavia na sistemática de tributação do ICMS por substituição tributária, o imposto por ser recolhido antecipadamente, provoca o recebimento antecipado pelo Governo do 
ICMS, que seria recolhido em cada etapa da cadeia produtiva e comercial, provocando um ônus sobre as empresas do "financiamento" antecipado do governo sobre as operações subseqüentes com mercadorias que ainda ocorrerão.

Ilustra-se este efeito no gráfico abaixo, adotando-se como premissa fictícia de que os "preços intermediários" não são afetados, e desconsiderando-se os prazos de pagamento do imposto previstos na legislação de cada Estado:

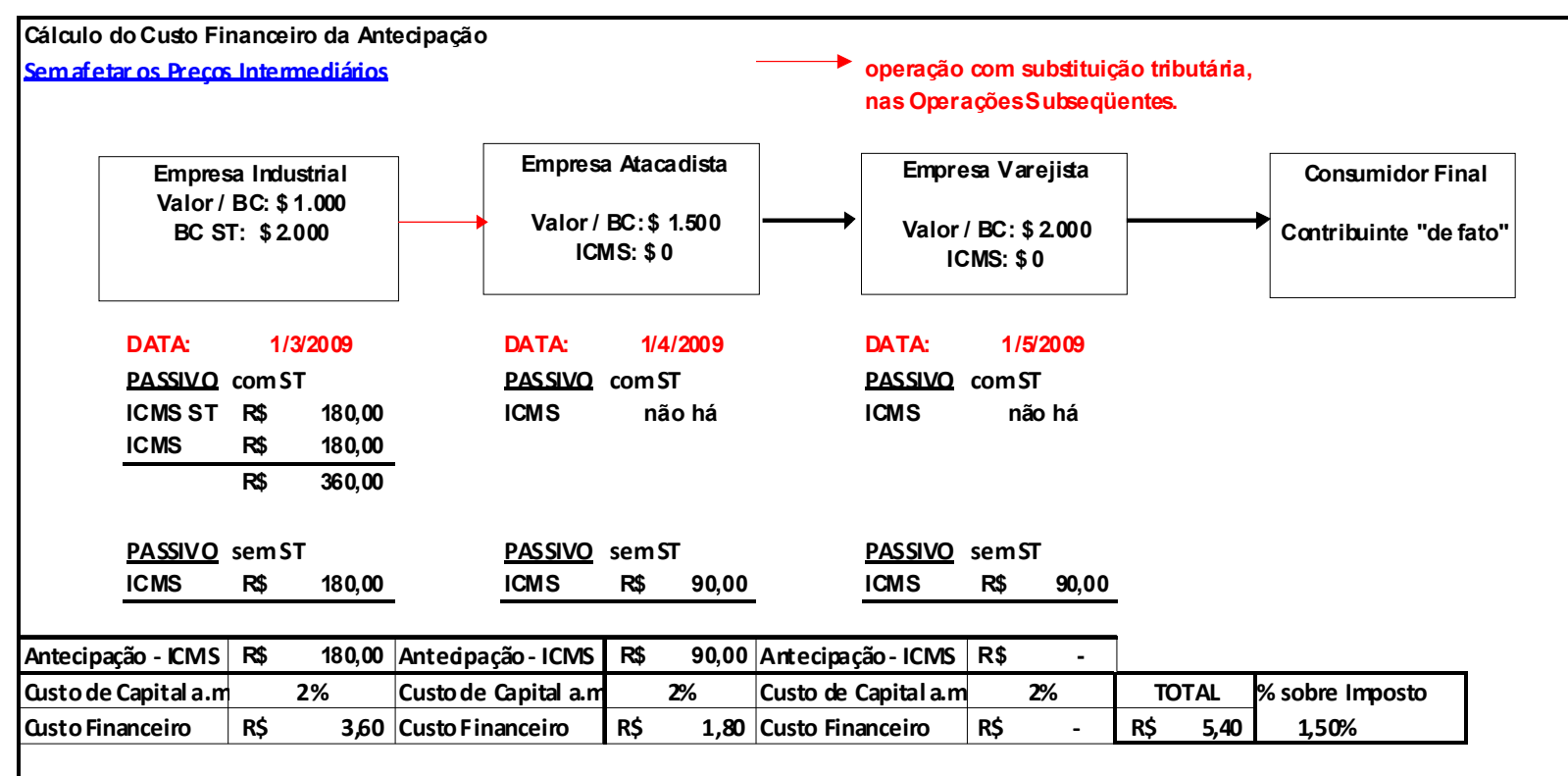

Figura 8: Cálculo do Custo Financeiro da Antecipação do ICMS

\subsection{Modelo II: Cálculo do Efeito do "Desconto" sobre o Preço Previsto (Base de Cálculo da ST) resultando em Recolhimento a Maior do Imposto:}

Inicialmente observa-se como seria a tributação pela sistemática normal do ICMS:

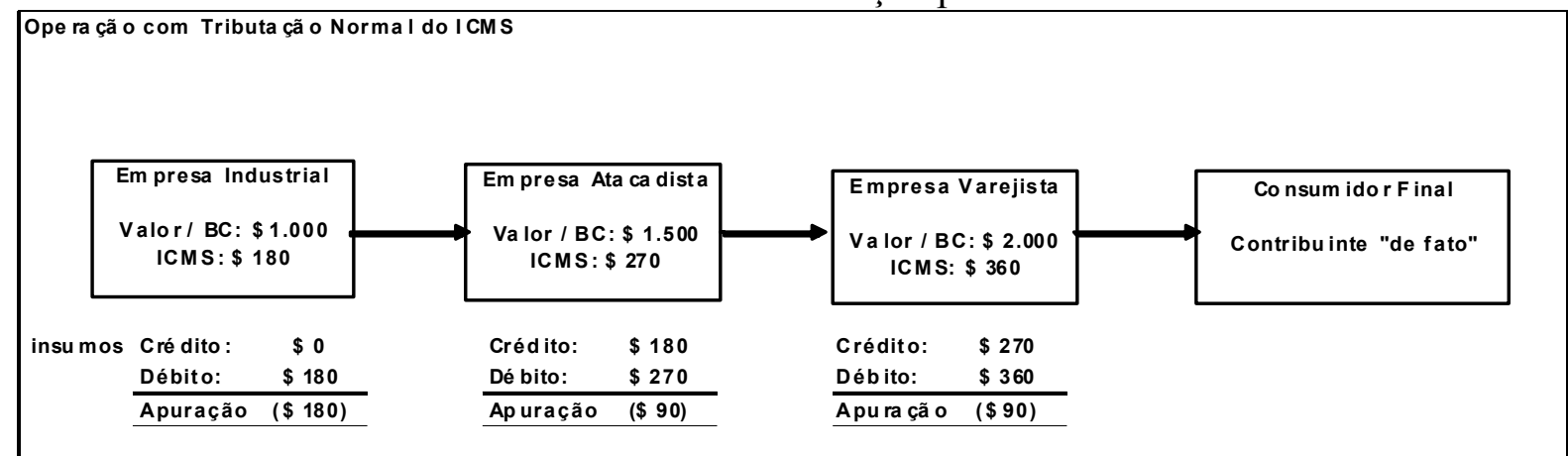

Figura 9: Tributação Normal do ICMS

Tendo em vista a sistemática de tributação do ICMS por substituição tributária, o imposto passa a ser recolhido antecipadamente já na $1^{\text {a }}$ etapa pelo preço final estimado (que chegará ao consumidor final) conforme novo gráfico: 


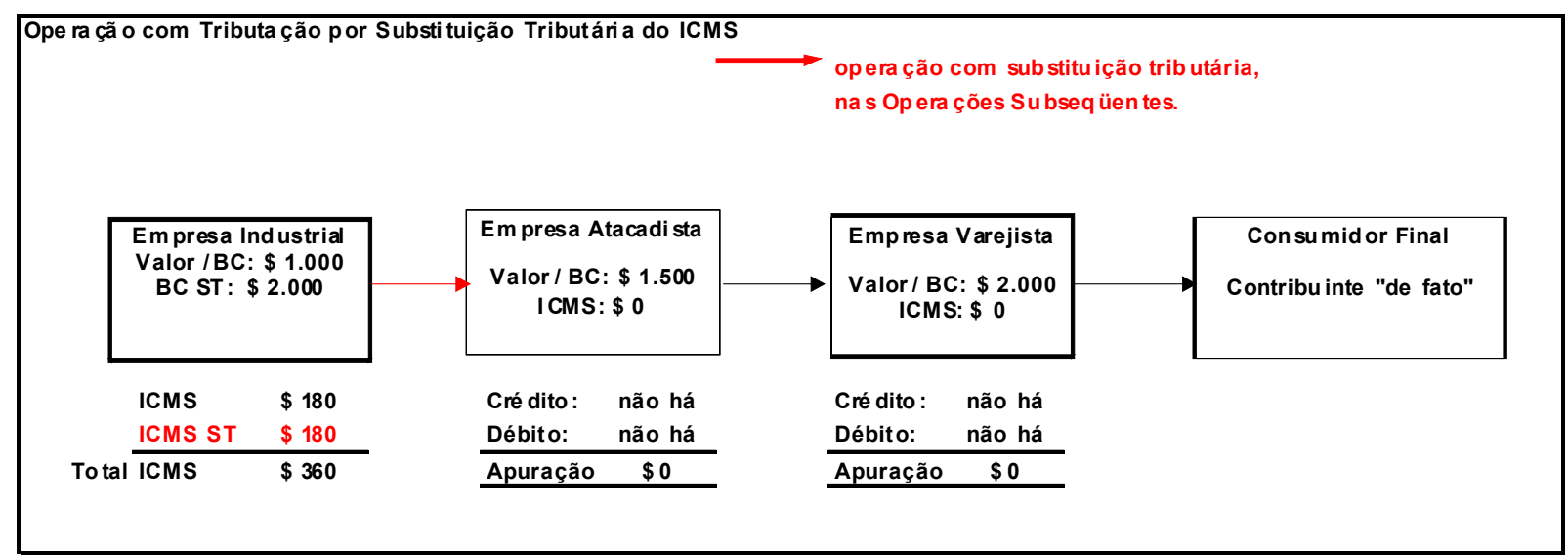

Figura 10: Tributação por Substituição Tributária do ICMS

Todavia na sistemática de tributação do ICMS por substituição tributária, o imposto recolhido antecipadamente é calculado por um preço final estimado ao consumidor final, que pode não ser exatamente o preço calculado pela base de cálculo da substituição tributária.

Assim, em uma situação que exista um "desconto" no preço ao consumidor em relação ao preço estimado (que serviu de base de retenção antecipada do ICMS, calculado conforme a legislação tributária), tem-se a seguinte situação conforme o novo gráfico:

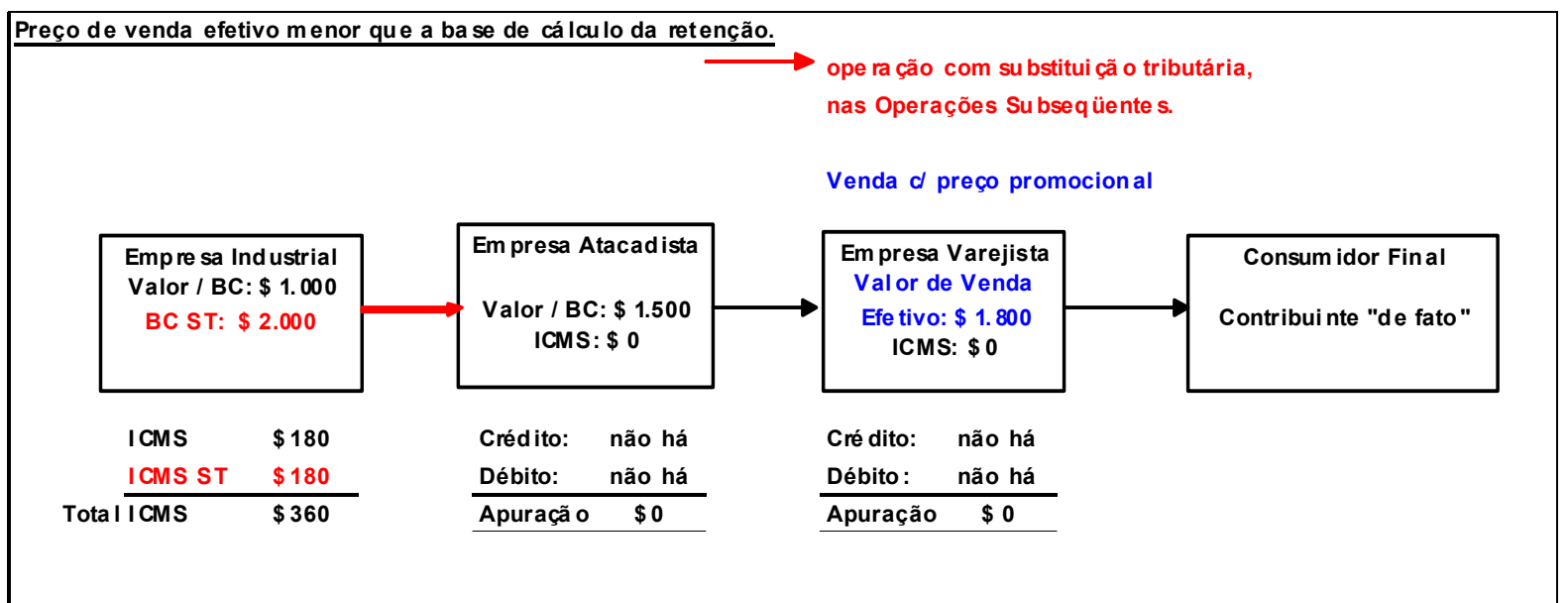

Figura 11: Substituição Tributária - "Preço de Venda Efetivo menor que a Base de Cálculo -ST"

Nesta situação acima exposta, verifica-se um recolhimento a maior do ICMS em R\$ 36,00 , ou seja, uma alíquota efetiva de $20 \%$ sobre um valor de venda de $\$ 1.800,00$, sendo que a alíquota do imposto nesta operação deveria ser pela legislação de $18 \%$, resultando em uma redução indevida da margem bruta das empresas do setor, conforme demonstramos o cálculo abaixo: 


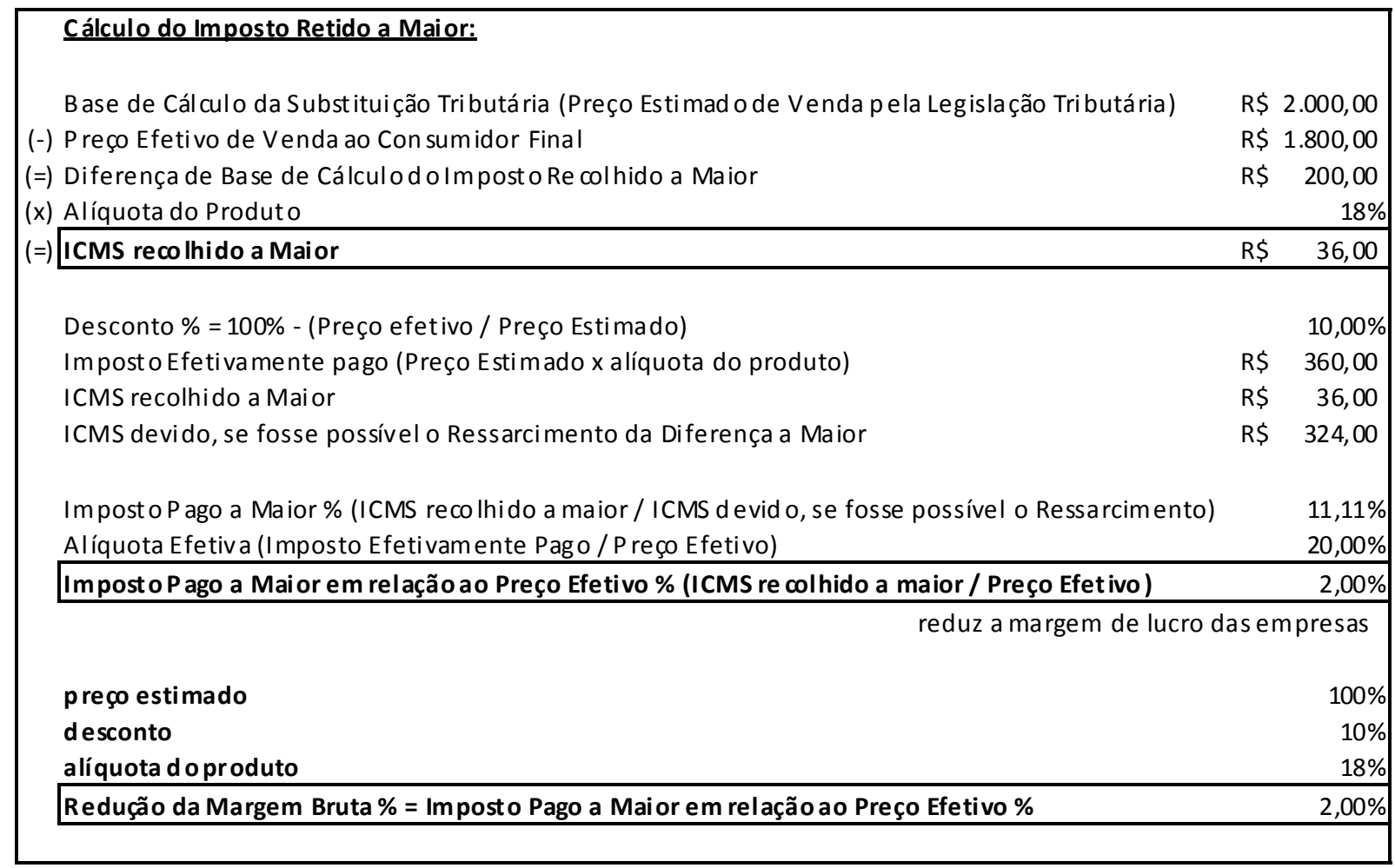

Figura 12: Cálculo Imposto Retido a Maior
- quando "Preço de Venda Efetivo menor que a Base de Cálculo -ST",

\subsection{Modelo III: Cálculo do Efeito da Existência de Empresas Varejistas, enquadradas no Simples Nacional (Microempresa ou Empresa de Pequeno Porte), no final da cadeia comercial de um produto sujeito à Substituição Tributária:}

Inicialmente observa-se como seria a tributação pela sistemática normal do ICMS, com o último varejista na Sistemática do Simples Nacional (com faturamento anual de até R\$ 120.000,00 e alíquota do ICMS de 1,25\%, com base no anexo I da Lei Complementar 123/2006):

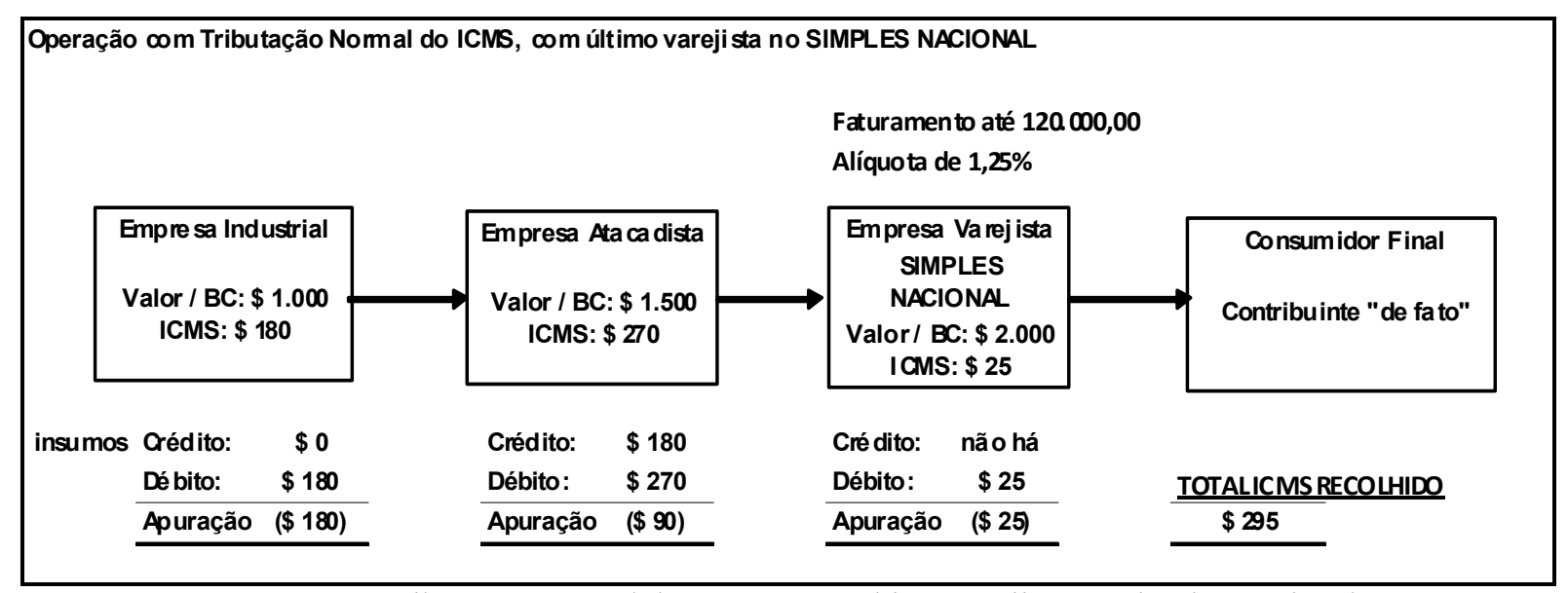

Figura 13: Tributação Normal do ICMS, com último varejista no Simples Nacional

Tendo em vista a sistemática de tributação do ICMS por substituição tributária, o imposto passa a ser recolhido antecipadamente já na $1^{\text {a }}$ etapa pelo preço final estimado (que chegará ao consumidor final) conforme novo gráfico, pouco importando aqui que a última empresa da cadeia comercial é contribuinte varejista optante do Simples Nacional: 


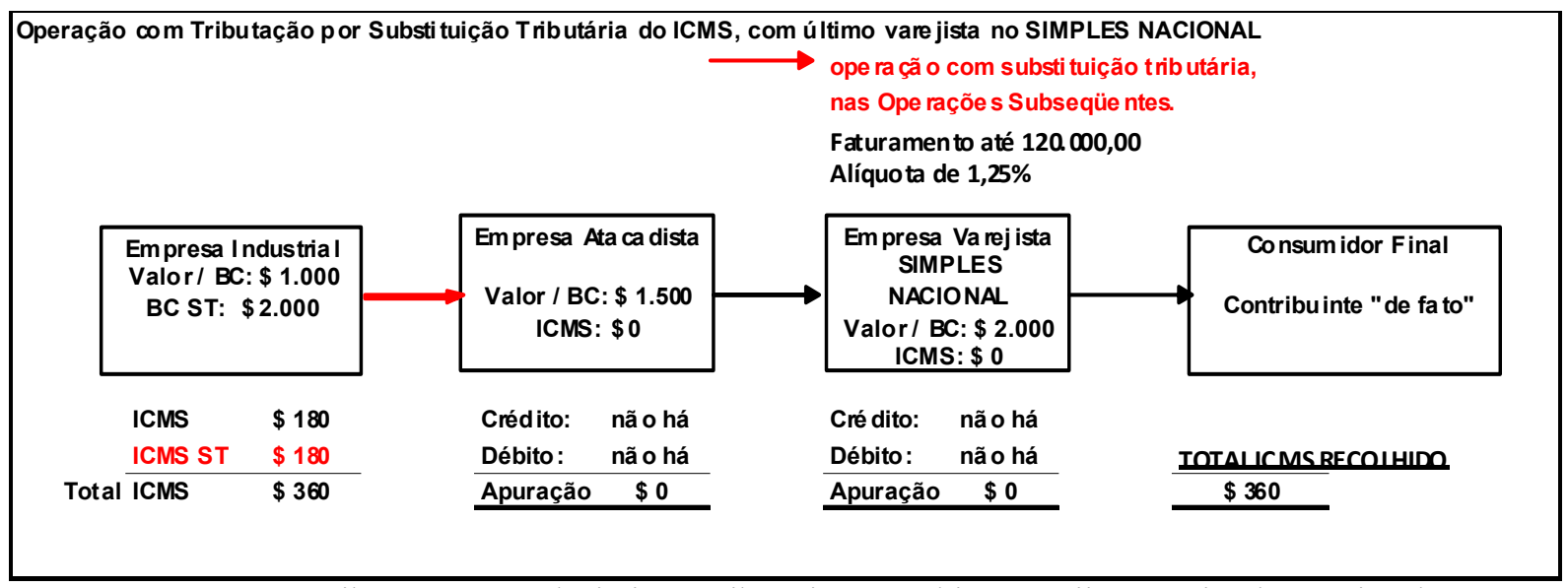

Figura 14: Tributação por Substituição Tributária, com último varejista no Simples Nacional

Nesta situação acima exposta, verifica-se um recolhimento a maior do ICMS em R\$ 65,00 , ou seja, uma alíquota efetiva de $18 \%$ (exatamente a alíquota interna do imposto, sem nenhum tratamento diferenciado para as empresas do Simples Nacional) sobre um valor de venda de R $\$ 2.000,00$, sendo que a alíquota efetiva do imposto nesta operação deveria ser de $14,75 \%$, se a operação não fosse tributada por substituição tributária e sim pela tributação normal combinada com o benefício tributário do Simples Nacional (ao varejista), resultando em uma redução indevida da margem bruta das empresas do setor, conforme demonstramos o cálculo abaixo:

\begin{tabular}{|c|c|c|}
\hline \multicolumn{3}{|l|}{ Cálculo do Imposto Retido a Maior: } \\
\hline Base de Cálculo da Substituição Tributária (Preço Estimad ode Ven da pe la Legislação Tributária) & $\mathrm{RSS}$ & $2000, \infty$ \\
\hline (x) Alíquota do Produto & & $18 \%$ \\
\hline (=) I mpos to Efe tivamente pago (Preço Esti mado x alíquota do produto) & $\mathrm{RS}$ & $360, \infty$ \\
\hline (-) ICMS que seria recolhido em toda a cad eia comercial, se a tributação nãoe stives se naST & $\mathrm{RS}$ & 295,00 \\
\hline$(=)$ ICMS recolhido a Mai or & $\mathrm{RS}$ & $65, \infty$ \\
\hline Preço da Mercadoria & $\mathrm{R} \$$ & $2000, \infty$ \\
\hline ICMS recolhido a Mai or & RȘ & 65,00 \\
\hline Impos to Pagoa Maior \% (ICMS recol hido a maior/ICMS devido, se nãohouvesse ST) & & $22,03 \%$ \\
\hline Alíquota Efetiva (Imposto Efetivamente Pago / Preço da mercadoria) & & $18,00 \%$ \\
\hline Alíquota Efetiva se nãohouvesse ST (Imposto queseria Pago se m ST / Preçoda mercadoria) & & $14,75 \%$ \\
\hline Impos to Pagoa Maior em relação ao Preço Efetivo \%(ICMS recolhido a maior /PreçoEfetivo) & & $3,25 \%$ \\
\hline \multicolumn{3}{|c|}{ 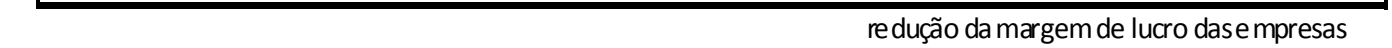 } \\
\hline
\end{tabular}

Figura 15: Cálculo Imposto Retido a Maior

- quando é eliminado o tratamento fiscal do varejista do Simples Nacional

Interessante destacar, que não há na legislação nenhuma previsão de ressarcimento do imposto, para estes casos de vendas por empresas varejistas do Simples Nacional. Pelo contrário, a adoção da sistemática da Substituição Tributária do ICMS, impossibilita que as empresas varejistas do Simples Nacional se aproveitem das vantagens das alíquotas menores por este sistema, já que o imposto já foi recolhido antecipadamente, independente de quem sejam os varejistas finais (se enquadrados na sistemática normal ou no simples nacional).

\section{CONSIDERAÇÕES FINAIS: CONCLUSÕES E RECOMENDAÇÕES}


O artigo teve como objetivo a compreensão prática da adoção e contabilização da sistemática de tributação da Substituição Tributária do ICMS e a análise dos principais impactos desta forma de tributação na lucratividade e nos custos empresariais através da proposição de três modelos práticos desenvolvidos pelos autores e embasados na legislação tributária vigente.

O artigo teve como contribuições: (i) aos empresários, a ampliação do conhecimento sobre os impactos da substituição tributária na lucratividade e nos custos empresariais; (ii) ao governo (e legisladores), um maior conhecimento em relação aos efeitos deste tipo de tributação nos agentes econômicos empresariais; (iii) aos estudantes e pesquisadores, uma contribuição didática no conhecimento deste fenômeno, pela construção de três modelos práticos, que avaliaram teoricamente os efeitos financeiros desta forma de tributação nas empresas, abrindo-se a possibilidade de desenvolvimento de pesquisas futuras, em entidades e em setores econômicos.

Assim, após a análise da aplicação dos modelos práticos no item anterior, concluí-se que com a utilização da técnica de Substituição Tributária do ICMS:

a) há aumento "indevido" de Custos Tributários com diminuição da Margem Bruta das empresas desta cadeia industrial/comercial, em virtude de o fisco tributar as operações, por uma "Base de Cálculo da Substituição Tributária" maior do que o preço ao consumidor final, quando a base de cálculo da substituição tributária for maior que o preço efetivo ao consumidor. Ou seja:

Técnica de Tributação (ICMS-ST) => Aumento “Indevido" do ICMS sobre Vendas (quando a base de cálculo da substituição tributária for maior que o preço ao consumidor final) $\Rightarrow$ Diminuição da Margem Bruta das Empresas da Cadeia Industrial/Comercial

b) há um desembolso antecipado das empresas do setor, que afeta o Fluxo de Caixa do Setor e a Necessidade de Capital de Giro das empresas e aumenta o Custo Financeiro / Custo de Oportunidade do Capital da Empresa. Ou seja:

Técnica de Tributação (ICMS-ST) $\Rightarrow$ Desembolso Antecipado de Tributos (afeta o Fluxo de Caixa do Setor e a Necessidade de Capital de Giro) => Maior Custo financeiro / Custo de Oportunidade do Capital da empresa)

c) há um aumento da carga tributária, pela falta de "Tratamento Tributário Diferenciado" para as empresas do Simples Nacional (Microempresas e das Empresas de Pequeno Porte), que comercializem produtos sob a sistemática da substituição tributária. $\mathrm{Ou}$ seja:

Técnica de Tributação (ICMS-ST) $\Rightarrow$ Pagamento antecipado do ICMS (sobre determinados produtos) no início da cadeia industrial/comercial $=>$ Varejistas no final da cadeia comercial, enquadrados no Simples Nacional $\Rightarrow$ ICMS já recolhido totalmente, independente de quais sejam os comerciantes finais (não há "tratamento tributário diferenciado" para as empresas do Simples Nacional)

Dessa forma, o presente artigo demonstrou três importantes impactos financeiros da substituição tributária do ICMS na lucratividade e nos custos empresariais, com modelos práticos, passíveis de aplicação empírica a casos concretos.

Como recomendações, tendo em vista as conclusões e resultados apresentados acima, recomenda-se (opinião dos autores) que para fins de aperfeiçoamento da legislação tributária do ICMS - Substituição Tributária que: (i) haja previsão em legislação aplicável a todos os Estados (Lei Complementar ou Convênio), de que seja assegurado o ressarcimento da diferença a maior, quando a base de cálculo da substituição tributária for maior que o preço ao consumidor final praticado; (ii) a legislação deveria prever prazos de pagamentos mais longos, específicos para cada segmento, que recomponham os prejuízos financeiros em virtude da 
antecipação do imposto, que afetam o fluxo de caixa e o capital de giro das empresas; (iii) no caso das empresas optantes do Simples Nacional, deveria a legislação tributária em nível nacional (todos os Estados) atribuir a possibilidade de um crédito especial aos microempresários, com base no valor da diferença entre seu preço de venda ao consumidor e seu preço de compra do fornecedor, aplicados pela diferença entre a alíquota interna do produto e a alíquota do Simples Nacional, que o mesmo estaria sujeito se pudesse ser tributado de acordo com a Lei Complementar 123/2006, de modo a permitir-lhe aproveitar do "tratamento tributário diferenciado" do Simples Nacional; ou não deveria ser aplicável a substituição tributária nas vendas para as empresas do Simples Nacional.

Como considerações finais, o presente artigo entende ter contribuído de forma produtiva, através dos três modelos apresentados, para as empresas e os governos avaliarem melhor a substituição tributária do ICMS, de modo a apontar para algumas (três) problemáticas desta sistemática de tributação, e ao mesmo tempo sugerir o debate de alternativas para o aperfeiçoamento desta legislação tributária.

\section{REFERÊNCIAS}

ASSAF N., Alexandre ; SILVA, C. A. T. . Administração do Capital de Giro. $3^{\text {a }}$. ed. São Paulo: Atlas, 2002.

ASSAF N., Alexandre . Estrutura e Análise de Balanços - Um Enfoque EconômicoFinanceiro. 8. ed. São Paulo: Atlas, 2006.

ASSAF N., Alexandre . Finanças Corporativa e Valor. São Paulo: Atlas, 2003.

ASSEF, Roberto. Manual de Gerência de Preços. Ed. Campus, 2002.

ATKINSON, Anthony et al. Contabilidade Gerencial. São Paulo, Atlas, 2000.

BRASIL. Constituição Federal 1988. Disponível em:

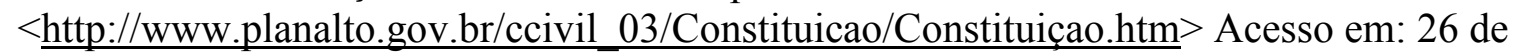
jul. 2010.

BRASIL. Lei Complementar n. ${ }^{\circ}$ 87, 13 de set. 1996. Dispõe sobre o imposto dos Estados e do Distrito Federal sobre operações relativas à circulação de mercadorias e sobre prestações de serviços de transporte interestadual e intermunicipal e de comunicação, e dá outras providências. Diário Oficial da República Federativa do Brasil, Brasília, 16 de set. 1996.

BRASIL. Lei Complementar n. ${ }^{\circ}$ 123, 14 de dez. 2006. Institui o Estatuto Nacional da Microempresa e da Empresa de Pequeno Porte. Diário Oficial da República Federativa do Brasil, Brasília, republicação em atendimento ao disposto no art. $6^{\circ}$ da Lei Complementar n. ${ }^{\circ} 128$, de 19 de dezembro de 2008.

BRUNI, Adriano Leal, FAMÁ, Rubens. Gestão de Custos e Formação de Preços. São Paulo: Atlas, 2004.

FABRETTI, Láudio Camargo. Contabilidade Tributária. São Paulo, Atlas, 2003.

GOVINDARAJAN, Vijai e ANTHONY, Robert N. Sistemas de Controle Gerencial. Ed. Atlas, 2006.

HENDRICKSEN, Eldo S.; VAN BREDA, Michael F. Teoria da Contabilidade. São Paulo: Atlas, 1999.

IUDÍCIBUS, S. Análise de Balanços - Livro Texto. São Paulo: Editora Atlas, 1998.

MATARAZZO, Dante C. Análise Financeira de Balanços: Abordagem Básica e

Gerencial. São Paulo, Atlas, 1998.

R. Cont. Ufba, Salvador-Ba, v. 4, n. 2, p. 71-91, maio-agosto 2010 
PEGAS, Paulo Henrique. Manual de Contabilidade Tributária. Rio de Janeiro: $5^{\text {a }}$ Ed.: Freitas Bastos, 2007.

ROSA, José Roberto. Substituição Tributária no ICMS. $2^{\mathrm{a}}$ edição. Itu: Ed. Ottoni, 2009. SANTOS, Ariovaldo dos. Demonstração do Valor Adicionado - como elaborar e analisar a DVA. $2^{\mathrm{a}}$ edição. São Paulo: Ed. Atlas, 2007. 